Yüzüncü Y1l Üniversitesi
Tarim Bilimleri Dergisi
Araştırma Makalesi (Research Article)
(YYU Journal of Agricultural Sciences)

\title{
Bitki Gelişimini Teşvik Eden Bakteri Uygulamalarının Kuraklık Stresi Koşullarında Yetiştirilen Aynısafa (Calendula officinalis L.) Bitkisinin Bazı Büyüme Parametreleri ile Fizyolojik Özellikleri Üzerine Etkisi
}

\author{
Ezelhan ŞELEM ${ }^{* 1}$, Lütfi NOHUTÇU² ${ }^{2}$ Rüveyde TUNÇTÜRK ${ }^{3}$, Murat TUNÇTÜRK ${ }^{4}$ \\ 1,2,3,4Van Yüzüncü Y1l Üniversitesi, Ziraat Fakültesi, Tarla Bitkileri Bölümü, 65100, Van, Türkiye \\ ${ }^{1}$ https://orcid.org/0000-0003-4227-5013 ${ }^{2}$ https://orcid.org/0000-0003-2250-2645 ${ }^{3}$ https://orcid.org/0000-0002-3759-8232 \\ ${ }^{4}$ https://orcid.org/0000-0002-7995-0599 \\ *Sorumlu yazar e-posta: ezelhanselem@hotmail.com
}

\section{Makale Bilgileri}

Geliş: 20.04.2021

Kabul: 03.09.2021

Online Yayınlanma: 15.12.2021

DOI: 10.29133 /yyutbd.922874

\section{Anahtar Kelimeler}

Fizyolojik değişim, Kurakl1k stresi, PGPR,

Stoma,

T1bbi bitki
Öz: Tıbbi özellikteki bitkiler arasında önemli bir yeri olan Calendula officinalis L. bitkisi farmakoloji, gıda, süs bitkisi ve kozmetik endüstrisinde değerlendirilmektedir. Son dönemlerde yapılan çalışmalarda aynısafa bitkisinin kullanım alanlarının gittikçe yaygınlaştı̆̆ı fakat yaygın kullanımına rağmen ticari olarak üretiminin oldukça sınırlı olduğu bilinmektedir. Tarımsal üretimde önemli bir abiyotik stres faktörü olan kuraklık stresine karşın verim ve kalitede düşüşleri en aza indirmek amaciyla BGUB (bitki gelişimini uyaran kök bakterileri) uygulamaları ön plana çıkmıştır. Yapılan bu çalışmada, BGUB ( $\mathrm{B}_{0}$ : Bakterisiz ortam (kontrol), $\mathrm{B}_{1}$; Azospirillum lipoferum, $\mathrm{B}_{2}$ : Bacillus megaterium, $\mathrm{B}_{3}$ : Chlorella saccharophila) uygulamalarının, kuraklık stresi koşullarında (normal sulama $\left(\mathrm{K}_{1}\right)$, $1 / 2$ azaltılmış $\left(\mathrm{K}_{2}\right)$ ve $3 / 4$ azaltılmış $\left(\mathrm{K}_{3}\right)$ ) yetiştirilen $C$. officinalis bitkisinin bazı büyüme parametreleri ile fizyolojik değişimleri üzerindeki etkilerinin tespit edilmesi amaçlanmıştır. Çalışma $8 / 16$ saatlik karanlık/aydınlık fotoperiyotta, $25^{\circ} \mathrm{C}$ sıcaklık ve \% 65 neme sahip olan kontrollü şartlardaki iklim odasında yürütülmüştür. Tohumlar 28.05.2020 tarihinde ekilmiş olup tesadüf parselleri deneme deseninde ve $3 \times 4$ faktöriyel düzende varyans analizine tabi tutulmuştur. Çalışmada, BGUB ( $\mathrm{B}_{0}$ : Bakterisiz ortam (kontrol), $\mathrm{B}_{1}$; Azospirillum lipoferum, $\mathrm{B}_{2}$ : Bacillus megaterium, $\mathrm{B}_{3}$ : Chlorella saccharophila) uygulamalarının, kuraklık stresi koşullarında (normal sulama $\left(K_{1}\right), 1 / 2$ azaltılmış $\left(K_{2}\right)$ ve $3 / 4$ azaltılmış $\left(K_{3}\right)$ ) yetiştirilen $C$. officinalis bitkisinin bazı büyüme parametreleri ile fizyolojik değişimleri üzerindeki etkilerinin tespit edilmesi amaçlanmıştır. İncelenen parametreler göz önüne alındığında kuraklık uygulamalarının gövde uzunluğu $\left(K_{1}\right.$ : $11.1 \mathrm{~cm})$, kök yaş $\left(\mathrm{K}_{1}: 1.06 \mathrm{~g}\right)$ ve kuru $\left(\mathrm{K}_{1}: 0.17 \mathrm{~g}\right)$ ağırlı̆̆ı, gövde yaş ağırlığ $1\left(\mathrm{~K}_{1}\right.$ : $7.26 \mathrm{~g})$, yaprak alanı $\left(\mathrm{K}_{1}: 7.81 \mathrm{~cm}^{2}\right)$ ve sicaklığı $\left(\mathrm{K}_{3}: 27.7^{\circ} \mathrm{C}\right)$, epidermal hücre sayısı $\left(\mathrm{K}_{1}: 593.16 \mathrm{adet} / \mathrm{mm}^{2}\right)$ ve stoma özelliklerinin tamamı istatistiksel olarak önemli görülmüştür. Bakteri uygulamalarında istatistiksel olarak gövde uzunluğu $\left(B_{1}: 11.0 \mathrm{~cm}\right)$, kök yaş $\left(B_{1}: 0.89 \mathrm{~g}\right)$ ağırlığ epidermal hücre sayıs1 $\left(\mathrm{B}_{1}: 672.88 \mathrm{adet} / \mathrm{mm}^{2}\right)$, stoma boyu $\left(\mathrm{B}_{1}: 32.71 \mu\right)$, ve yoğunluğunun $\left(\mathrm{B}_{1}: 11.06\right.$ adet $\left./ \mathrm{mm}^{2}\right)$ önemli olduğu belirlenmiştir. 


\section{The Effect of Plant Growth Promoting Rhizobacteria Applications on Some Growth Parameters and Physiological Properties of Marigold (Calendula officinalis L.) Plant Grown under Drought Stress Conditions}

\section{Article Info}

Received: 20.04 .2021

Accepted: 03.09.2021

Online Published: 15.12.2021

DOI:10.29133/yyutbd.922874

\section{Keywords}

Physiological change,

Drought stress,

PGPR,

Stoma,

Medicinal plant.

\begin{abstract}
Calendula officinalis L. species, which has an important place among medicinal plants, is used in the pharmacology, food, ornamental plant, and cosmetics industry. In recent studies, It is known that the usage areas of marigold have become increasingly widespread, but despite this widespread use, the species is quite limited of commercial production. Against drought stress, which is an important abiotic stress factor in agricultural production, BGUB (plant growthpromoting rhizobacteria) applications have come to the fore in order to minimize the decrease in yield and quality. In this study, it is aimed to determine the effects of PGPR ( $\mathrm{B}_{0}$ : Bacteria-free environment (control), $\mathrm{B}_{1}$; Azospirillum lipoferum, $\mathrm{B}_{2}$ : Bacillus megaterium, $\mathrm{B}_{3}$ : Chlorella saccharophila) applications on some growth parameters and physiological changes of $C$. officinalis plant grown under drought stress (normal irrigation $(\mathrm{K} 1)$, reduced $1 / 2\left(\mathrm{~K}_{2}\right)$ ve reduced $3 / 4\left(\mathrm{~K}_{3}\right)$ ) conditions. The study was carried out in a controlled climate room with a temperature of $25^{\circ} \mathrm{C}$ and a humidity of $65 \%$ in a dark/light photoperiod of $8 / 16$ hours. Seeds were sown on 28.05.2020 and were subjected to analysis of variance in randomized plot design and $3 \times 4$ factorial design. In this study, it is aimed to determine the effects of BGUKB ( $\mathrm{B}_{0}$ : Bacteria-free environment (control), $\mathrm{B}_{1}$; Azospirillum lipoferum, $\mathrm{B}_{2}$ : Bacillus megaterium, $\mathrm{B}_{3}$ : Chlorella saccharophila) applications on some growth parameters and physiological changes of $C$. officinalis plant grown under drought stress (normal irrigation $(\mathrm{K} 1)$, reduced $1 / 2\left(\mathrm{~K}_{2}\right)$ ve reduced $3 / 4\left(\mathrm{~K}_{3}\right)$ ) conditions. Considering the parameters examined, drought applications were found to be statistically significant in terms of stem length $\left(\mathrm{K}_{1}: 11.1 \mathrm{~cm}\right)$, root fresh $\left(\mathrm{K}_{1}: 1.06\right.$ $\mathrm{g})$ and dry $\left(\mathrm{K}_{1}: 0.17 \mathrm{~g}\right)$ weight, stem fresh $\left(\mathrm{K}_{1}: 7.26 \mathrm{~g}\right)$ weight, leaf area $\left(\mathrm{K}_{1}: 7.81\right.$ $\left.\mathrm{cm}^{2}\right)$ and temperature $\left(\mathrm{K}_{3}: 27.7{ }^{\circ} \mathrm{C}\right)$, epidermal cell number $\left(\mathrm{K}_{1}: 593.16\right.$ number $/ \mathrm{mm}^{2}$ and all stomatal characteristics. In conclusion, bacteria applications showed a significant impact on some of the characters like stem length $\left(\mathrm{B}_{1}: 11.0\right.$ $\mathrm{cm})$, root fresh $\left(\mathrm{B}_{1}: 0.89 \mathrm{~g}\right)$ weight, stem fresh $\left(\mathrm{B}_{1}: 6.09 \mathrm{~g}\right)$ weight, epidermal cell number $\left(\mathrm{B}_{1}: 672.88\right.$ number $\left.\mathrm{mm}^{-2}\right)$, stoma length $\left(\mathrm{B}_{1}: 32.71 \mu\right)$ and density $\left(\mathrm{B}_{1}\right.$ : 11.06 number $\left(\mathrm{mm}^{2}\right)$.
\end{abstract}

\section{Giriş}

Calendula son dönemlerde ön plana çıkmıș tıp ve kozmetik sektörünün önemli bitkileri arasına girmiştir. Aynısafa olarak da bilinen Calendula officinalis L. Asteraceae familyasından olup sarıturuncu renkli çiçeklere sahip 30-70 cm boyunda tek yıllık otsu bir türdür. İlkbahar ayından sonbahara kadar çiçekte kalan tür, bünyesinde flavonlar, müsilaj, saponinler, glikozitler, sapogenin, ksantofil, karatinoid, eterik yağlar ve organik asitleri bulundurmaktadır (Ebcioğlu, 2013). Kozmetik sanayisinde çiçeklerinin onarıcı, nemlendirici, yenileyici ve yatıştırıcı etkisinden kaynaklı diş macunu, bebek yağı, cilt bakım kremi ve şampuan olarak kullanıldığı bilinmektedir (Göktaş ve Gıdık, 2019). Ayrıca antibakteriyel, antifungal, iştah açıcı, sindirimi kolaylaştırıcı, tansiyonu düşürücü ve mide ülserinde etkili olduğu belirtilmiştir (Ebcioğlu, 2013).

Dünyada sürekli olarak artan gıda ve hammadde ihtiyacının karșılanabilmesi için su kaynaklarının etkin kullanılması gerekmektedir. Mevcut su kaynaklarının tükenmesine bağlı olarak kuraklık stresi tarımsal üretimi güçleştirmektedir (Samancıŏlu ve ark., 2016). Kısıtlı sulama tarımsal üretimde önemli bir abiyotik stres faktörü olarak görülmektedir. Yapılan çalışmalarda kuraklık stresi altındaki bitkilerde meydana gelen fizyolojik ve morfolojik zararların BGUB ile en aza indirilebileceği vurgulanmıştır (Samancıoğlu ve ark., 2016; Kutsal, 2017). BGUB uygulamalarında bitki gelişimi için önemli olan azot ve fosfor gibi besin elementlerinin bitkiye kazandırılması büyük önem taşımaktadır. Önemli azot bağlayıcı bakterilerden olan Azospirillum lipoferum 'un bitkilerde verim artışı, geniş kök sistemi, çimlenme ve gelişimi teşvik ettiği bilinmektedir (Jacoud ve ark., 1998). Proteince zengin olan mikroalgler ürettikleri bazı enzim ve hormonlar sayesinde bitki gelişimini teşvik ederken canlılığını 
yitirenlerinde ayrışarak bitkilere inorganik maddeler sağladığı belirtilmiştir (Ergün ve ark., 2010). Açık sistemlerde en çok yetiştirilen mikroalglerden olan Chlorella'nın bazı meyve kalite parametrelerini $\operatorname{arttırdığ~} 1$, bitki gelişimi ve verimi teşvik ettiği ortaya konulmuştur (Özenç ve Şen, 2017). Bitki gelişimi ve veriminde önemli fosfat çözücü bakterilerden olan Bacillus megaterium ise organik ve inorganik fosfatı kullanılabilir forma dönüştürerek bitki tarafından alınımı artırmakta ve antibiyotik ile indol asetik asit gibi metabolitleri üreterek bitki gelişimini teşvik etmektedir (Yolcu ve ark. 2012; Öztekin ve ark., 2015).

Biyolojik gübre olarak tek veya kombine olarak kullanılan bu mikroorganizmaların bitki gelişimini teşvik ettiği yapılan araştırmalar ile ortaya konmuş ve stres altındaki bitkilerde oluşacak tahribatların en aza indirilmesi noktasında çözüm olabileceği öngörülmüştür. Ayrıca bitkisel üretimde üretkenliği ve fotosentezi sınırlayan kuraklık ile mücadelede bölgeye uygun tür ve çeşitlerin yetiştirilmesi önemlidir. Bu noktada seleksiyon kriteri olarak stoma boyutları ve yoğunluğunun bir belirteç olarak kullanılabileceği ortaya konmuştur (Çınar ve ark., 2016). C. officinalis türünün anomositik stoma içerdiği, stomaların yaprağın her iki yüzeyinde de bulunduğu ve epiderma hücreleriyle aynı seviyede (mezomorf stoma) olduğu bildirilmiştir (Kalas, 2019).

Çalışma materyalini oluşturan C. officinalis türünün Türkiye florasında kültür formu olduğu, gen merkezinin bilinmediği belirtilmiş fakat mevcut literatürde türün kökeninin Akdeniz havzası olduğu ve bitkinin artık ülkemizde doğallaşmaya başladığı ortaya konmuştur (Kalas, 2016). Yapılan çalışmada farklı kuraklık uygulamalarına tabi tutulan Calendula officinalis L. bitkisinde BGUB uygulamalarının bazı büyüme ve fizyolojik parametreler üzerine olan etkisi araştırılmıştır.

\section{Materyal ve Yöntem}

Çalışmanın bitkisel materyalini oluşturan Calendula officinalis L. bitkisine ait tohumlar Van Yüzüncü Y1l Üniversitesi (Van YYÜ) Tibbi ve Aromatik Bitkiler Bahçesi'nden temin edilmiştir. Çalışma Van YYÜ Ziraat Fakültesi Tarla Bitkileri Bölümü İklim odası ve Fizyoloji laboratuvarında yürütülmüş̧ür. C. officinalis L. türüne ait tohumlar $500 \mathrm{cc}$ ' lik saksılarda torf+perlit+toprak $(1: 1: 2)$ ortamına 1-2 cm derinliğe dört tekerrürlü olarak ekilmiştir. Ekimden sonra bitkiler 8/16 saatlik karanlık/aydınlık fotoperiyotta, $25^{\circ} \mathrm{C}$ sıcaklık ve \% 65 neme sahip olan kontrollü şartlardaki iklim odasında yetiştirilmiştir.

Çalışmada kullanılan toprak kumlu killi tın tekstür yapısında, kireçli (\% 17.9), pH alkali reaksiyonlu (8.18) olup tuz oranı (\% 0.021), organik madde (\% 1.17), azot içeriği $(0.049 \mathrm{me} / 100 \mathrm{~g})$ ve yarayışlı fosfor içeriği $(6.70 \mathrm{ppm})$ ile potasyum $(488 \mathrm{ppm})$ miktarı belirlenmiştir. Çalışmada kullanılan torfa ait özellikler; pH 6, 160-260 mg/L N, 180- $280 \mathrm{mg} / \mathrm{L} \mathrm{P}_{2} \mathrm{O}_{5}, 200-150 \mathrm{mg} / \mathrm{L} \mathrm{K}_{2} \mathrm{O}_{5}, 80-150 \mathrm{mg} / \mathrm{L}$ $\mathrm{Mg}, \% 0.8 \mathrm{~N}, \% 70$ organik madde, \% $35 \mathrm{C}$ şeklindedir.

Tohumlar 28.05.2020 tarihinde toprağa ekilmiş ve bitkilerin 5-6 yapraklı olduğu dönemde kısıtlı sulamaya başlanmıştır. Kısıtlı sulama uygulamalarına başlamadan önce saksı (tarla) kapasitesi Ünlükara ve ark. (2010)'na göre $130 \mathrm{cc}$ olarak belirlenmiştir. Sulama suyu miktarı olarak 500 cc'lik saksılara üç farklı su rejimi uygulaması (normal $(\% 100)$ sulama $\left(\mathrm{K}_{1}\right), 1 / 2$ azaltılmış $\left(\mathrm{K}_{2}\right)$ ve $3 / 4$ azaltılmış $\left(\mathrm{K}_{3}\right)$ ) yapılmış ve bitkiler distile su ile sulanmıştır. Çalışmada bitki gelişimini teşvik edici bakterilerden $\mathrm{N}$ bakterisi olan Azospirillum lipoferum ( $\left.1 \times 10^{6} \mathrm{kob} / \mathrm{ml}\right)$, P çözücü olarak bilinen Bacillus megaterium $\left(1 \times 10^{5} \mathrm{kob} / \mathrm{ml}\right)$ ve tatlı su algi olan Chlorella saccharophila $\left(2 \times 10^{4} \mathrm{kob} / \mathrm{ml}\right)$ kullanılmıştır. Kontrol grubunda herhangi bir bakteri uygulaması yapılmamıştır. C. officinalis tohumları hazırlanan karışımlarda 2 saat karanlıkta bekletilerek 500 cc'lik saksılara ekilmiştir. Ekimden 1 hafta sonra uygulamalar dikkate alınmak üzere saksılara $50 \mathrm{cc}$ bakteri solüsyonu uygulanmıştır.

Kök ve gövde uzunluğu dijital kumpas yardımıyla cm olarak ölçülmüştür. Kök ile gövdenin yaş ve kuru ağırlığı hassas terazi (0.0001 g duyarlı) yardımıyla tartılmıştır. Yaş ağırlıkları belirlenen bitki ve kökler daha sonra $40^{\circ} \mathrm{C}^{\prime}$ de 72 saat süreyle kurutulmuştur. Yaprak alanı Easy Leaf Area programı kullanılarak, yaprak yüzey sıcaklıkları taşınabilir infrared termometre yardımıyla ölçülmüştür. Bitkilerden alınan yaprak örnekleri stoma analizleri için Laboratuvara taşınmıştır. Stoma ölçümlerinde Leica DM500 1şık mikroskobu, mikroskoba bağlı Leica ICC50 HD kamera ile Leica LAS EZ (versiyon 3.0) yazılımı kullanılmıştır. Stoma yoğunluklarını belirlemek amacıyla bitkinin 2. yapraklarının alt kısmına tırnak cilası sürülmüş ve kuruduktan sonra alınıp lam üzerine konularak mikroskopta incelenmiştir. Ölçümler 3 bitkiden alınan yapraklardan toplamda 10 ölçüm olacak şekilde yapılmıştır. Alana düşen stoma sayısı $\mathrm{mm}^{2}$, lik alana düşen sayı olarak belirlenmiştir (Eriş ve Soylu, 1990). 
Epidermal hücre sayısı $\mathrm{mm}^{2}$ alana düşen hücrelerin sayılması ile yapılmıştır. Stoma indeksinin hesaplanmasında aşağıdaki formül kullanılmıştır (Meidner ve Mansifield, 1968).

Stoma indeksi $=\mathrm{mm}^{2}$, deki stoma sayıs1 $/\left(\mathrm{mm}^{2}\right.$ deki stoma say1si $+\mathrm{mm}^{2}$, deki epidermis hücre say1s1) x100.

Çalışmanın sonucunda elde edilen veriler, Tesadüf Parselleri deneme deseninde ve $3 \times 4$ faktöriyel düzende varyans analizine tabi tutulmuştur. Elde edilen verilerin hesaplanması COSTAT (6.3 versiyonu) bilgisayar analiz programı kullanılarak yapılmış olup önemli çıkan uygulamalar Duncan Çoklu Karşılaştırma Yöntemi’ ne göre karşılaştırılmıştır (Düzgüneş ve ark., 1987).

\section{Bulgular ve Tartışma}

Bitkilerde büyüme ve gelişmeyi olumsuz yönde etkileyen kuraklık stresinin biyokimyasal, morfolojik, fizyolojik ve moleküler değişikliklere sebep olduğu bilinmektedir. Yürütülen çalışmada farklı bakteri uygulamaları ve kuraklık uygulamalarına tabi tutulan $C$. officinalis türünde meydana gelen değişimler incelenmiştir. Türde meydana gelen morfolojik ve anatomik değişimler Çizelge 1 ve 2'de verilmiş̧tir.

Çalışmada kuraklık uygulamaları (KU), bakteri uygulamaları (BU) ve KU x BU interaksiyonunun kök uzunluğu üzerinde istatistiksel olarak önemli olmadığı görülmüsşür. Kuraklık stresinde kök uzunluğu değeri 14.9-16.8 cm ve bakteri uygulamalarına göre kök uzunluğu değeri 15.6$16.7 \mathrm{~cm}$ arasında değişmektedir. Kalas (2019), C. officinalis' in ana kök yapısının odunsu ve 5.2-21.9 $\mathrm{cm}$ uzunluğunda olduğunu vurgulamıştır. Çalışma sonucunda elde edilen kök uzunluğunun ilgili literatür ile paralellik gösterdiğgi görülmüştür. Ayrıca kurak şartlarda yetiştirilen çeltik bitkisine uygulanan BGUB'nin kök büyümesini ve saçak kök oluşumunu artırdığı ve bu gelişmenin glisinbetain, prolin gibi ozmolitlerin artışından kaynaklanabileceği görüşü savunulmuştur (Yuwono ve ark., 2005).

Çalışmada gövde uzunluğu bakımından kuraklık uygulamalarının etkisi \% 1, bakteri uygulamalarının etkisi \% 5 düzeyinde istatistiksel olarak önemli bulunurken, KU x BU interaksiyonunun etkisi ise önemsiz bulunmuştur. Kuraklık uygulamalarına göre en uzun gövde boyu $10.7 \mathrm{~cm}$ ile $\mathrm{K}_{2}$ uygulamasından elde edilirken, $\mathrm{K}_{1}$ uygulaması ile aynı grup içerisinde yer almıştır. En az gövde uzunluğu $(8.58 \mathrm{~cm})$ değeri ise $\mathrm{K}_{3}$ uygulamasından tespit edilmiştir. Bitkinin vejetatif aksamındaki gelişimde etkili olduğu bilinen $\mathrm{N}$ bakterisinin bulunduğu $\mathrm{B}_{1}$ uygulamasından $11.0 \mathrm{~cm}$ ile en yüksek ortalama elde edilirken en düşük değer $9.34 \mathrm{~cm}$ ile $\mathrm{B}_{3}$ uygulamalarından tespit edilmiştir. Kuraklık stresinin bitkilerde fotosentez oranında düşüşlere neden olduğu, dolayısıyla bitki gelişimini olumsuz etkileyerek büyümeyi sınırlandırdığı ortaya konmuştur (Sayyari ve Ghanbari, 2012). Telek ve ark. (2019), rhizobakterilerin bitki boyu, sürgün kuru ve yaş ağırlığı özellikleri üzerine geliştirici etkisinin olduğunu rapor etmiştir. Deng ve ark. (2013), yaptı̆̆ 1 çalışmada Paenibacillus polymyxa izolatının domates bitkisinin boyunda artış sağladığını saptamıştır. Çalışmanın sonucunda artan kuraklık uygulamalarına bağlı olarak büyüme ve gelişmede azalmalar görülürken bakteri uygulamalarında artışların olduğu ve literatürle benzerlik gösterdiği belirlenmiştir.

Kök yaş ağırlı̆̆ından elde edilen veriler incelendiğinde istatistiksel olarak kuraklık uygulamalarının \% 1, bakteri uygulamalarının \% 5 ve KU x BU interaksiyonunun da önemsiz olduğu görülmüştür. Artan kuraklık uygulamalarına bağlı olarak ortalamaların sırayla $1.06,0.76$ ve $0.58 \mathrm{~g}$ olduğu ve kuraklık stresindeki artışa paralel olarak ağırlıklarında azalmaların olduğu saptanmıştır. Bakteri uygulamaları ortalamasında ise en yüksek değer $(0.89 \mathrm{~g}) \mathrm{B}_{1}$ uygulamalarından, en düşük değerin ise $(0.74 \mathrm{~g}) \mathrm{B}_{0}$ uygulamalarından elde edildiği tespit edilmiştir. Kontrol uygulamaları ile $\mathrm{B}_{2}$ uygulamaları aynı grup içerisinde yer almıştır. Bat ve ark. (2020), ekinezya bitkisinde deniz yosunu uygulamalarının yaş kök ağırlığında artış sağlarken $(5.93 \mathrm{~g})$ en düşük yaş kök ağırlığının kontrol grubunda (4.26 g) olduğunu belirtmiştir. Telek ve ark. (2019), biberde bakteri uygulamalarının kök yaş ve kuru ağırlığ yetiştirilen bitkilerde bitki yaş ve kuru ağırlıklarında azalışların olduğunu ortaya koymuştur (Khorasaninejad ve ark., 2011). Elde ettiğimiz bulguların ilgili literatürler ile uyumlu olduğu görülmüştür.

Araştırma sonucunda kök kuru ağırlı̆̆ iken kuraklık uygulamaları ve KU x BU interaksiyonunda istatistiksel olarak \% 1 düzeyinde önemli görülmüştür. Bakteri uygulamalarında en yüksek değer $0.16 \mathrm{~g}$ olarak $\mathrm{B}_{3}$ uygulamalarından, en düşük değerin ise $0.14 \mathrm{~g}$ ile $\mathrm{B}_{2}$ uygulamalarından belirlenmiştir. Kuraklık uygulamalarında; kök kuru ağırlığı 
bakımından en yüksek değer $0.17 \mathrm{~g}$ ile $\mathrm{K}_{1}$ uygulamalarından, en düşük değer ise $0.13 \mathrm{~g}$ ile $\mathrm{K}_{3}$ uygulamalarından tespit edilmiş̧ir. $\mathrm{K}_{2}$ ile $\mathrm{K}_{3}$ uygulamaları arasında istatistiksel farklılığın olmadığı Çizelge 1' de görülmektedir. KU x BU interaksiyonunda en fazla kök kuru ağırlığ değeri $K_{1}$ x $B_{1}$ ile $K_{2}$ x $\mathrm{B}_{0}$ interaksiyonlarından $0.19 \mathrm{~g}$ olarak tespit edilmiştir. Osakabe ve ark. (2014), yaptığ çalışmada kuraklık stresinin bitkilerde $\mathrm{N}$ alımını artırdığı ve $\mathrm{P}$ alımını azalttığını belirtmiş̧ir. Çalışmamızda benzer şekilde en düşük kuru kök ağırlı̆̆ının $B_{2}$ ortamında olduğu görülmüştür. Kuraklık stresine bağlı olarak bitkilerde kök uzaması, su alımında azalma, yaprakların kıvrılması, epidermal iletkenlik, kök ve gövdenin kuru-yaş ağırlıklarında azalmaların olduğu yapılan çalışmalar ile ortaya konmuştur (Tuteja ve ark., 2011).

Gövde yaş ağırlığı verilerine bakıldığında kuraklık uygulamalarının istatistiksel olarak \% 1, bakteri uygulamalarının \% 5 düzeyinde önemli olduğu, KU x BU interaksiyonunun ise önemsiz olduğu tespit edilmiştir. Bakteri uygulamalarına göre; en yüksek değer $6.09 \mathrm{~g}$ ile $\mathrm{B}_{1}$ uygulamalarından tespit edilirken $\mathrm{B}_{0}$ ve $\mathrm{B}_{2}$ uygulamaları ile aynı grupta yer almıştır. En düşük değer ise $4.80 \mathrm{~g}$ ile $\mathrm{B}_{3}$ uygulamalarından belirlenmiştir. Gövde yaş ağırlığının artan kuraklık dozuna bağlı olarak azaldığı ve ortalamaların sırasıyla 7.26, 5.85 ve $3.91 \mathrm{~g}$ aralığında değiştiği belirlenmiştir. En yüksek değer $7.26 \mathrm{~g}$ ile kontrolden, en düşük değer ise $3.91 \mathrm{~g}$ ile $\mathrm{K}_{3}$ uygulamalarından tespit edilmiştir. Kuşvuran ve Abak (2012), 31 kavun genotipi ile gerçekleştirdiği kuraklık çalışmasında ilk belirgin etkiler bitkilerin yeşil aksam ağırlığında azalma olduğunu ve kontrol bitkilerine kıyasla \% 60-67 oranında gövde yaş ağırlığında azalma olduğunu vurgulamıştır. Samancıŏ̆lu ve ark. (2016), kısıtlı sulama altında yetiştirdiği lahana bitkisinde en yüksek gövde yaş ve kuru ağırlığının Bacillus subtilis rizobakterisinin uygulandığı bitkilerden elde edildiğini belirtmiştir.

Elde edilen veriler doğrultusunda kuru gövde ağırlığının kuraklık uygulamalarında istatistiksel olarak \% 1 düzeyinde önemli olduğu, bakteri uygulamaları ve KU x BU interaksiyonunda önemsiz olduğu belirlenmiştir. Kuru gövde ağırlığının artan kuraklık uygulamalarına paralel olarak azalış gösterdiği ve kuraklık dozu ortalamalarının sırasıyla 1.27, 1.11, $0.97 \mathrm{~g}$ olduğu tespit edilmiştir. Kuraklık stresine bağlı olarak büyümede azalma, bitki yaş ve kuru ağırlığ gibi parametrelerde azalma meydana geldiği bildirilmektedir (Kusvuran ve ark., 2008). Sankar ve ark. (2008), kuraklık stresine maruz bırakılan bamyada kuru ağırlık kayıplarının \% 78 oranında gerçekleştiğini bildirirken, Kuşvuran ve ark. (2007), Cucumis sp. genotiplerinde kuraklığın köklerde kuru ağırlığın azaldığını belirtmiştir.

Bakteri uygulamalarının yaprak alanı üzerindeki etkisi istatistiksel olarak önemsiz bulunurken BU x KU interaksiyonu ile kuraklık uygulamaları istatistiksel olarak \% 1 oranında önemli bulunmuştur. Kuraklık stresi şartlarında en fazla yaprak alanı $7.81 \mathrm{~cm}^{2}$ ile kontrol uygulamalarından en düşük değer $\left(5.43 \mathrm{~cm}^{2}\right)$ ise $\mathrm{K}_{3}$ uygulamalarından tespit edilmiştir. $\mathrm{K}_{2}$ uygulamaları ile aynı grup içerisindedir. En yüksek yaprak alanı $\mathrm{K}_{1} \times \mathrm{B}_{0}$ interaksiyonunda $9.85 \mathrm{~cm}^{2}$ olarak, en düşük ise $\mathrm{K}_{2} \times \mathrm{B}_{0}$ interaksiyonunda $4.42 \mathrm{~cm}^{2}$ olarak elde edilmiştir. $\mathrm{K}_{3} \times \mathrm{B}_{0}$ uygulamaları ile aralarında istatistiksel farklılığın olmadığ Çizelge 1'de görülmektedir. Azotun bitkilerde vejetatif aksamı geliştirdiği çeşitli çalışmalar ile tespit edilmiştir (Bolat ve Kara, 2017; Aşık, 2018). Samancıoğlu ve ark. (2016), kısıtlı sulama altında yetiştirdiği lahanada en yüksek yaprak alanının Bacillus subtilis rizobakterisinin uygulandığı bitkilerden elde edildiğini belirtmiştir. Bat ve ark. (2020), kuraklık stresinin bitkilerde yaprak alanının azalmasına neden olduğunu ortaya koymuştur. Yapılan çalışmalarda bitkilerde artan stres dozuna bağlı olarak yaprak alanının azaldığ1 vurgulanmış (Tuteja ve ark., 2011) ve bu sonuçların çalışmamız ile uyumlu olduğu görülmüştür. Dere (2021), sıv1 bakteri biyogübresi (Basillus subtilis $\left(1 \times 10^{9}\right)$, Bacillus licheniformis $\left(2 \times 10^{6}\right)$, Bacillus megaterium $\left(1 \times 10^{9}\right)$ ve Pseudomonas putita $\left.\left(1 \times 10^{10}\right)\right)$ kullanarak yaptığ çalışmada kuraklık stresi altında yetiştirilen Falcon domates çeşidinin bitki çapı, kök yaş ağırlı̆̆ 1 ve yaprak alanı parametrelerinin, Tom-29 domates çeşidinde ise bitki yaş ağırlığı, yaprak yaş ağırlığı, kök yaş ağırlığı ve yaprak alanının olumlu etkilediğini, kuraklık stresinin bu parametrelere olan olumsuz etkisini azalttığını belirlemiştir.

Bitkide yaprak yüzey sıcaklıklarının, çevreden, bitkinin fenolojik durumundan ve topraktaki nem eksikliğinden etkilendiği bilinmektedir. Yaprak sıcaklığında meydana gelen değişimler bakteri uygulamalarında önemli farklılıklar göstermezken kuraklık uygulamalarında artan strese paralel olarak sıcaklık artışının istatistiksel olarak \% 1 düzeyinde önemli olduğu ve en yüksek yaprak sıcaklığının $27.8^{\circ} \mathrm{C}$ ile $\mathrm{K}_{3}$ uygulamalarından, en düşük değerin ise $26.7^{\circ} \mathrm{C}$ ile kontrolden sağlandığ tespit edilmiştir. Araştırmacılar artan stres dozlarına bağlı olarak bitkilerin yaprak sıcaklığında artışların olduğunu bilmişlerdir (Akçay ve Eşitken, 2016). Yapılan çalışmada elde edilen sonuçlarda strese bağlı olarak sicaklığın artış gösterdiği görülmüştür. 
Çizelge 1. Farklı kuraklık uygulamalarına tabi tutulan C. officinalis' de meydana gelen bazı fizyolojik ve morfolojik değişimler

\begin{tabular}{|c|c|c|c|c|c|c|c|c|}
\hline $\begin{array}{l}\text { Kuraklık } \\
\text { dozları }\end{array}$ & $\begin{array}{l}\text { Bakteri } \\
\text { Uygulamaları }\end{array}$ & $\begin{array}{l}\text { Kök } \\
\text { uzunluğu } \\
\text { (cm) }\end{array}$ & $\begin{array}{l}\text { Gövde } \\
\text { uzunluğu } \\
(\mathrm{cm})\end{array}$ & $\begin{array}{l}\text { Kök } \\
\text { yaş } \\
\text { ağırlığ } \\
\text { (g) }\end{array}$ & $\begin{array}{l}\text { Kök } \\
\text { kuru } \\
\text { ağırlığ } 1 \\
\text { (g) }\end{array}$ & $\begin{array}{l}\text { Gövde } \\
\text { yaş } \\
\text { ağırlığ1 } \\
(\mathrm{g})\end{array}$ & $\begin{array}{l}\text { Gövde } \\
\text { kuru } \\
\text { ağırlığ1 } \\
\text { (g) }\end{array}$ & $\begin{array}{l}\text { Yaprak } \\
\text { alanı } \\
\left(\mathrm{cm}^{2}\right)\end{array}$ \\
\hline \multirow{4}{*}{$\mathrm{K}_{1}$} & $\mathrm{~B}_{0}$ & 19.8 & 11.5 & 0.94 & 0.17 & 7.02 & 1.10 & $9.85 a$ \\
\hline & $\mathrm{B}_{1}$ & 15.9 & 12.8 & 1.23 & 0.19 & 8.56 & 1.31 & $8.20 \mathrm{a}$ \\
\hline & $\mathrm{B}_{2}$ & 17.0 & 10.0 & 1.05 & 0.18 & 7.46 & 1.39 & $7.03 \mathrm{ab}$ \\
\hline & $\mathrm{B}_{3}$ & 14.5 & 10.0 & 1.02 & 0.16 & 6.01 & 1.28 & $6.15 \mathrm{ab}$ \\
\hline Ort. & & 16.8 & $11.1 \mathrm{a}$ & $1.06 \mathrm{a}$ & $0.17 \mathrm{a}$ & $7.26 \mathrm{a}$ & $1.27 \mathrm{a}$ & $7.81 \mathrm{a}$ \\
\hline \multirow{4}{*}{$\mathrm{K}_{2}$} & $\mathrm{~B}_{0}$ & 17.3 & 10.6 & 0.84 & 0.19 & 6.32 & 1.26 & $4.42 b$ \\
\hline & $\mathrm{B}_{1}$ & 17.0 & 10.9 & 0.75 & 0.13 & 5.58 & 1.14 & $7.51 \mathrm{ab}$ \\
\hline & $\mathrm{B}_{2}$ & 15.0 & 11.2 & 0.64 & 0.12 & 6.61 & 1.10 & $6.11 \mathrm{ab}$ \\
\hline & $\mathrm{B}_{3}$ & 17.2 & 9.90 & 0.81 & 0.17 & 4.90 & 0.92 & $6.00 \mathrm{ab}$ \\
\hline Ort. & & 16.6 & $10.6 \mathrm{a}$ & $0.76 \mathrm{~b}$ & $0.15 b$ & $5.85 \mathrm{~b}$ & $1.11 \mathrm{~b}$ & $6.01 \mathrm{~b}$ \\
\hline \multirow{4}{*}{$\mathrm{K}_{3}$} & $\mathrm{~B}_{0}$ & 12.9 & 9.03 & 0.44 & 0.10 & 4.10 & 1.09 & $4.57 b$ \\
\hline & $\mathrm{B}_{1}$ & 15.5 & 9.30 & 0.68 & 0.15 & 4.13 & 0.87 & $5.73 \mathrm{ab}$ \\
\hline & $\mathrm{B}_{2}$ & 14.8 & 8.96 & 0.56 & 0.13 & 3.91 & 0.89 & $5.73 \mathrm{ab}$ \\
\hline & $\mathrm{B}_{3}$ & 16.3 & 8.13 & 0.65 & 0.15 & 3.48 & 1.04 & $5.70 \mathrm{ab}$ \\
\hline Ort. & & 14.9 & $8.58 \mathrm{~b}$ & $0.58 \mathrm{c}$ & $0.13 b$ & $3.91 \mathrm{c}$ & $0.97 b$ & $5.43 b$ \\
\hline \multirow{4}{*}{ BU Ort. } & $\mathrm{B}_{0}$ & 16.7 & $10.4 \mathrm{ab}$ & $0.74 b$ & 0.15 & $5.81 \mathrm{a}$ & 1.15 & 6.28 \\
\hline & $\mathrm{B}_{1}$ & 16.1 & $11.0 \mathrm{a}$ & $0.89 \mathrm{a}$ & 0.15 & $6.09 \mathrm{a}$ & 1.11 & 7.15 \\
\hline & $\mathrm{B}_{2}$ & 15.6 & $10.0 \mathrm{ab}$ & $0.75 b$ & 0.14 & $5.99 \mathrm{a}$ & 1.13 & 6.29 \\
\hline & $\mathrm{B}_{3}$ & 16.0 & $9.34 b$ & $0.82 \mathrm{ab}$ & 0.16 & $4.80 \mathrm{~b}$ & 1.08 & 5.95 \\
\hline $\mathrm{VK}(\%)$ & & 17.69 & 10.29 & 13.69 & 17.12 & 15.15 & 14.71 & 15.94 \\
\hline KU & & öd & $* *$ & $* *$ & $* *$ & $* *$ & $* *$ & $* *$ \\
\hline $\mathrm{BU}$ & & öd & $*$ & $*$ & öd & $*$ & öd & öd \\
\hline $\mathrm{KU} \times \mathrm{BU}$ & & öd & öd & öd & $* *$ & öd & öd & $* *$ \\
\hline
\end{tabular}

Kuraklık uygulamaları: $\mathrm{K}_{1}$ : normal sulama (Kontrol), $\mathrm{K}_{2}: 1 / 2$ azaltılmıs, $\mathrm{K}_{3}: 3 / 4$ azaltılmıș; Bakteri uygulamaları: $\mathrm{B}_{0}$ : Bakterisiz ortam(Kontrol), $\mathrm{B}_{1}$; Azospirillum lipoferum, $\mathrm{B}_{2}$ : Bacillus megaterium, $\mathrm{B}_{3}$ : Chlorella saccharophila, BU: Bakteri uygulamaları, KU: Kuraklık uygulamaları, öd: önemli değil.

*P $<0.05$ düzeyinde, ${ }^{* *} \mathrm{P}<0.01$ düzeyinde önemli olup, ortalamalar arasındaki fark Duncan çoklu karşılaştırma metoduyla $\mathrm{P}<0.05$ seviyesinde değerlendirilmiş̧ir.

Kuraklık stresinin bitkilerdeki en belirgin hasarının morfolojik gelişimindeki gerileme olduğu bilinmektedir. Kuraklık stresinin artması yapraklardaki stomaların boyutlarının küçülmesine ve yoğunluğunun azalmasına neden olmuştur. Şekil 1'de C. officinalis'e ait stoma ve epidermal hücrelerin mikroskobik çekimleri verilmiştir. Stomalar üzerinde kuraklık dozunun ve bakteri uygulamalarının etkisi istatistiksel olarak \% 1 düzeyinde önemli bulunmuştur. Yapılan mikroskobik ölçümlerde KU x BU interaksiyonunda stoma boyunun önemsiz olduğu görülmüştür. Kuraklık uygulamaları bakımından en yüksek stoma boyu $32.8 \mu \mathrm{m}$ ile kontrolden sağlanırken $\mathrm{K}_{1}$ uygulamaları ile istatistiksel bir farklılık bulunmamaktadır. En düşük değer ise $28.6 \mu \mathrm{m}$ ile $\mathrm{K}_{3}$ uygulamalarından tespit edilmiş̦tir. Stoma boyutlarının artan strese paralel olarak azaldığı belirlenmiştir. Bakteri uygulamalarına göre en fazla stoma boyu $32.7 \mu \mathrm{m}$ ile $\mathrm{B}_{1}$ ' den elde edilirken, $\mathrm{B}_{2}$ uygulamaları ile aynı grup içerisinde yer almıştır. En küçük stoma boyu ise $28.8 \mu \mathrm{m}$ ile kontrolden sağlanmıştır. $\mathrm{N}$ elementinin bitki büyümesinde etkili olduğu ve özellikle yeşil aksamların gelişiminde önemli bir besin elementi görevi gördüğü bilinmektedir (Bolat ve Kara, 2017). Kara ve ark. (2018), İtalya üzüm çeşidinde kısıtlı sulamanın stoma eni ve boyunda artış meydana getirdiğini belirtmiştir. Çalışma sonucunda elde edilen verilere göre $C$. officinalis bitkisinin kuraklık stresine farklı tepkiler verdiği görülmüştür. Çınar ve ark. (2016), yer fıstı̆̆ında en uzun stoma boyunun $28.10 \mu \mathrm{m}$ ile \% 100 sulamanın yapıldığ 1 bitki yapraklarından, en kısa stoma boyunun ise $23.17 \mu \mathrm{m}$ ile sulanmayan konu altında yetiştirilen bitki yapraklarından elde edildiğini ortaya koymuştur. Meng ve ark. (1999) çeltikte; HtayHtay ve ark. (2005) fasulyede; Karipçin (2009) karpuzda; 
Özyurt (2011) mahlepde benzer sonuçlara ulaşmışlardır. Elde edilen sonuçların çalışmamız ile paralellik gösterdiği görülmüştür.

Stoma eni üzerinde, kuraklık stresinin etkisi istatistiksel olarak \% 1 ve KU x BU interaksiyonunun etkisi \% 5 düzeyinde önemli bulunurken, bakteri uygulamalarının etkisi önemsiz bulunmuştur. Kuraklık stresi bakımından en yüksek stoma eni $22.9 \mu \mathrm{m} \mathrm{K}_{1}$ uygulamalarından elde edilirken, $\mathrm{K}_{2}$ uygulamaları ile aynı grupta yer almıştır. En düşük stoma eni değeri ise $20.6 \mu \mathrm{m}$ olarak $\mathrm{K}_{3}$ uygulamalarından tespit edilmiştir. En yüksek stoma eni değeri $24.9 \mu \mathrm{m}$ olarak $\mathrm{B}_{2} \times \mathrm{K}_{2}$ interaksiyonundan, en düşük stoma eni değeri ise $19.4 \mu \mathrm{m} \mathrm{B}_{0} \mathrm{x} \mathrm{K}_{3}$ interaksiyonundan elde edilmiştir. Yapraklardaki stoma yoğunluğu yüksek çeşitlerin stoma genişliklerinin daha dar olduğu bildirilmektedir (Mert ve ark., 2009). Çınar ve ark. (2016), yerfıstı̆̆ında artan su stresinin stoma eninde azalmalara neden olduğunu bildirmiştir. Bahereh (2020), Zn stresinin artan dozlarında stoma eninin azalış gösterdiği ve $19.6 \mu \mathrm{m} \pm 0.5-23.8 \pm 0.8 \mu \mathrm{m}$ aralı̆̆ında değiştiğini belirtmiştir. Benzer ş̧ekilde Çınar ve ark. (2016), yerfıstığı bitkisinde su kısıtının stoma eninde azalmaya neden olduğunu vurgulamıştır. Türkiye florasında Calendula türünün kültür formu olduğu bilinmekte ve bu bitkilerin stoma yapıları ile yoğunluklarının bilinmesi bitki-su dengesinin kontrolü açısından önemli olduğu vurgulanmıştır (Çağlar ve ark., 2004). Stoma boyutlarının farklı türlerde hatta çeşitlerde değişiklik gösterdiği bilinmektedir (Şelem ve ark., 2020). Dolayısıyla bitkilerdeki stoma özellikleri yetiştiricilikte kuraklık direnci olan türlerin seçiminde önemli bir parametre olarak ön plana çıkmaktadır.

Yürütülen çalışmada elde edilen verilerde stoma yoğunluğunun kuraklık dozu, bakteri uygulaması ve bunların interaksiyonlarının istatistiksel olarak \% 1 düzeyinde önemli olduğu görülmüştür. Stoma yoğunluklarının en yüksek $\mathrm{K}_{2} \times \mathrm{B}_{3}$ interaksiyonunda $141.7 \mathrm{adet} / \mathrm{mm}^{2}$, en düşük $\mathrm{K}_{3}$ $\mathrm{x} \mathrm{B}_{2}$ interaksiyonunda $48.3 \mathrm{adet} / \mathrm{mm}^{2}$ olduğu belirlenmiştir. Bakteri uygulamalarında ise en yüksek stoma yoğunluğu değeri 111.1 adet $/ \mathrm{mm}^{2}$ olarak B3 uygulamalarından tespit edilirken, B0 uygulamaları ile aynı grupta yer almıştır. En düşük değer ise 73.1 adet $/ \mathrm{mm}^{2}$ olarak B1 uygulamalarından tespit edilmiş olup B2 uygulamaları ile aynı grup içerisinde yer almaktadırlar. Stoma yoğunluklarının tür, uygulamalar hatta klonlar arasında dahi değişiklik gösterdiği bilinmektedir. Doğan ve ark. (2020), yaptıkları çalışmada yaprağın alındığı konumun stoma yoğunluğu üzerine olan etkisinin önemli olduğunu ancak yaprak yüzeyinin farklı bölgelerinden örnek almanın stoma yoğunluğu üzerine etkisinin önemsiz olduğunu tespit etmiştir. Kurt ve Doğan (2020), 11 fındık çeşidinde yaptıkları çalışmada stoma yoğunluklarının 90.00 ile $111.60 \mathrm{adet} / \mathrm{mm}^{2}$ aralığında değiştiğini belirlemiştir. Marasali ve Aktekin (2003), sulanan ve sulanmayan bağ koşullarında yetiştirilen 17 üzüm çeşidinden iki tanesinin kurak şartlarda, dokuz tanesinin ise sulu şartlarda en yüksek stoma yoğunluğuna sahip olduğunu ortaya koymuştur. Kara ve ark. (2018), İtalya üzüm çeşidinde kısıtlı sulamanın stoma yoğunluğunda azalmalar meydana getirdiğini rapor etmiştir. Türün belirlenen kuraklık uygulamalarındaki strese toleranslı olduğu ve bundan kaynaklı stoma yoğunluklarında azalmaların olmadığı düşünülmektedir.

Epidermal hücre sayısının da tüm faktörler açısından istatistiksel olarak \% 1 düzeyinde önemli olduğu görülmüştür. Kuraklık stresi bakımından en fazla epidermal hücre sayısı $593.2 \mathrm{adet} / \mathrm{mm}^{2}$ ile $\mathrm{K}_{1}$ 'den, en düşük değer ise $530.2 \mathrm{adet} / \mathrm{mm}^{2}$ olarak $\mathrm{K}_{2}$ ' den tespit edilmektedir. Bakteri uygulamaları bakımından en yüksek değer 672.9 adet $/ \mathrm{mm}^{2}$ ile $\mathrm{B}_{3}$ uygulamalarından elde edilirken, kontrol uygulamas1 ile aynı grupta yer almıştır. En düşük değer ise 445.1 adet $/ \mathrm{mm}^{2}$ ile $\mathrm{B}_{1}$ uygulamalarından tespit edilmiştir. KU x BU interaksiyonu bakımından en yüksek değer 795.8 adet $/ \mathrm{mm}^{2}$ ile $\mathrm{K}_{3}$ x $\mathrm{B}_{0}$ interaksiyonundan tespit edilmiştir. Çınar ve ark. (2016), Arachis hypogaea L. bitkisinde su stresinin stomalar üzerindeki etkisini araştırmış sulanmayan bitkilerde 625.0 adet $\mathrm{mm}^{2}$ ile en fazla epidermal hücre sayısına sahipken en düşük epidermal hücre sayısına 471.9 adet $/ \mathrm{mm}^{2}$ ile buharlaşmanın tamamının uygulandığ bitki yapraklarından elde etmişlerdir. Çalışmamızda epidermal hücrelerin sayısının stres dozuna bağlı dalgalanmalar gösterdiği belirlenmiştir. Bakteri uygulamalarında $\mathrm{B}_{1}$ 'de bitkilerin en az epidermal hücre sayısına sahip olduğu görülmüş olup bu durumun bitkilerin vejetatif aksamlarını geliştiren $\mathrm{N}$ elementi ile alakalı olduğu sonucuna varılmıştır. C. officinalis türünün belirlenen kuraklık uygulamalarına toleranslı olduğu ve bu sebeple belirtilen parametrede artışların olmadığı görülmüştür. Elde edilen veriler ışığında türün özellikle kurak ve yarı kurak bölgelerde iyi bir adaptasyon sağlayacağı öngörülmektedir.

Stoma indeksinde ise kuraklık uygulamaları ile KU x BU interaksiyonunun istatistiksel olarak $\% 1$ düzeyinde önemli olduğu bakteri uygulamalarının ise önemsiz olduğu belirlenmiştir. Kurakl1k stresi uygulamaları bakımından en yüksek stoma indeksi değeri \% 17.6 ile $\mathrm{K}_{2}$ ' den, en düşük değer ise \% 10.7 ile $\mathrm{K}_{3}$ ' ten elde edilmiştir. En yüksek stoma indeksinin $\mathrm{B}_{2} \times \mathrm{K}_{2}$ interaksiyonunda \% 23.2, en düşük 
değerin ise $\mathrm{B}_{2} \times \mathrm{K}_{3}$ interaksiyonunda \% 9.01 olduğu tespit edilmiştir. Çınar ve ark. (2016), Arachis hypogaea L. bitkisinde farklı sulama suyu seviyelerinin stoma indeksinde etkili olduğu ve artan kuraklığa bağlı olarak \% 30.1 ile \% 33.1 aralığında değişiklik gösterdiğini vurgulamışlardır. Sarker ve Hara (2011), patlıcan bitkisinde su stresi arttıkça epidermal hücre sayısı ve stoma indeksinin arttığını belirlemiştir. Yapılan çalışmadan farklı olarak bitkilerde stoma indeksinin uygulamalar arasında değişiklik gösterdiği görülmüştür. Bu farklılığın çalışma materyalini oluşturan türün belirlenen kuraklık uygulamalarına karşı toleranslı olduğunu göstermektedir.

Çizelge 2. Farlı kuraklık uygulamalarına tabi tutulan C. officinalis'de meydana gelen bazı fizyolojik değişimler

\begin{tabular}{|c|c|c|c|c|c|c|c|}
\hline $\begin{array}{l}\text { Kuraklık } \\
\text { uygulamaları }\end{array}$ & $\begin{array}{l}\text { Bakteri } \\
\text { Uygulamaları }\end{array}$ & $\begin{array}{l}\text { Yaprak } \\
\text { S1caklığ1 } \\
\left({ }^{\circ} \mathrm{C}\right)\end{array}$ & $\begin{array}{l}\text { Stoma } \\
\text { boyu } \\
(\mu \mathrm{m})\end{array}$ & $\begin{array}{l}\text { Stoma eni } \\
(\mu \mathrm{m})\end{array}$ & $\begin{array}{l}\text { Stoma } \\
\text { yoğunluğu } \\
\left(\operatorname{adet} / \mathrm{mm}^{2}\right)\end{array}$ & $\begin{array}{l}\text { Epidermal } \\
\text { hücre sayis1 } \\
\left(\text { adet } / \mathrm{mm}^{2}\right)\end{array}$ & $\begin{array}{l}\text { Stoma } \\
\text { indeksi } \\
(\%) \\
\end{array}$ \\
\hline \multirow{4}{*}{$\mathrm{K}_{1}$} & $\mathrm{~B}_{0}$ & 26.3 & 31.12 & $23.68 \mathrm{abc}$ & $115.88 \mathrm{abc}$ & $470.83 \mathrm{~cd}$ & $19.71 \mathrm{ab}$ \\
\hline & $\mathrm{B}_{1}$ & 26.7 & 34.17 & $22.59 \mathrm{abc}$ & $98.66 \mathrm{~cd}$ & $579.16 \mathrm{bc}$ & $14.51 \mathrm{cde}$ \\
\hline & $\mathrm{B}_{2}$ & 26.6 & 31.41 & $21.13 \mathrm{~cd}$ & $101.68 \mathrm{c}$ & $691.5 \mathrm{~b}$ & $12.44 \mathrm{def}$ \\
\hline & $\mathrm{B}_{3}$ & 27.1 & 34.48 & $24.26 \mathrm{ab}$ & $112.5 \mathrm{bc}$ & $631.16 \mathrm{~b}$ & $15.28 \mathrm{bcd}$ \\
\hline Ort. & & $26.7 \mathrm{c}$ & $32.79 a$ & $22.91 \mathrm{a}$ & $107.18 \mathrm{a}$ & $593.16 a$ & $15.48 \mathrm{~b}$ \\
\hline \multirow{4}{*}{$\mathrm{K}_{2}$} & $\mathrm{~B}_{0}$ & 26.9 & 28.67 & $20.16 \mathrm{~cd}$ & $125.53 \mathrm{ab}$ & $643.66 b$ & $16.33 \mathrm{bc}$ \\
\hline & $\mathrm{B}_{1}$ & 27.0 & 33.53 & $22.27 b c$ & $67.35 \mathrm{ef}$ & $368.66 \mathrm{de}$ & $15.5 \mathrm{bc}$ \\
\hline & $\mathrm{B}_{2}$ & 27.4 & 36.06 & $24.88 \mathrm{a}$ & $95.89 \mathrm{~cd}$ & $316.66 \mathrm{e}$ & $23.22 \mathrm{a}$ \\
\hline & $\mathrm{B}_{3}$ & 27.3 & 31.74 & $22.89 \mathrm{abc}$ & $141.66 \mathrm{a}$ & $791.66 \mathrm{a}$ & $15.14 \mathrm{~cd}$ \\
\hline Ort. & & $27.17 \mathrm{~b}$ & $32.50 \mathrm{a}$ & $22.55 \mathrm{a}$ & $107.61 \mathrm{a}$ & $530.16 b$ & $17.55 \mathrm{a}$ \\
\hline \multirow{4}{*}{$\mathrm{K}_{3}$} & $\mathrm{~B}_{0}$ & 27.8 & 26.67 & $19.42 \mathrm{~d}$ & $88.86 \mathrm{~cd}$ & $795.83 a$ & $10.11 \mathrm{fg}$ \\
\hline & $\mathrm{B}_{1}$ & 27.8 & 30.42 & $20.26 \mathrm{~cd}$ & $53.32 \mathrm{fg}$ & $387.5 \mathrm{~d}$ & $12.12 \mathrm{ef}$ \\
\hline & $\mathrm{B}_{2}$ & 27.7 & 30.06 & $21.75 \mathrm{c}$ & $48.33 \mathrm{~g}$ & $487.5 \mathrm{c}$ & $9.01 \mathrm{~g}$ \\
\hline & $\mathrm{B}_{3}$ & 27.6 & 27.10 & $21.20 \mathrm{c}$ & $79.01 \mathrm{de}$ & $595.83 \mathrm{bc}$ & $11.69 \mathrm{ef}$ \\
\hline Ort. & & $27.7 \mathrm{a}$ & $28.56 b$ & $20.66 \mathrm{~b}$ & $67.38 \mathrm{~b}$ & $566.66 \mathrm{ab}$ & $10.73 \mathrm{c}$ \\
\hline \multirow{4}{*}{$\mathrm{BU}$} & $\mathrm{B}_{0}$ & 27.0 & $28.82 b$ & 21.09 & $110.09 \mathrm{a}$ & $636.77 \mathrm{a}$ & 15.38 \\
\hline & $\mathrm{B}_{1}$ & 27.2 & $32.71 \mathrm{a}$ & 21.70 & $73.11 \mathrm{~b}$ & $445.11 \mathrm{c}$ & 14.04 \\
\hline & $\mathrm{B}_{2}$ & 27.2 & $32.51 \mathrm{a}$ & 22.59 & $81.97 \mathrm{~b}$ & $498.55 b$ & 14.89 \\
\hline & $\mathrm{B}_{3}$ & 27.3 & $31.10 \mathrm{ab}$ & 22.79 & $111.06 \mathrm{a}$ & $672.88 \mathrm{a}$ & 14.04 \\
\hline $\mathrm{VK}(\%)$ & & 1.11 & 7.75 & 7.27 & 11.28 & 7.94 & 10.02 \\
\hline $\mathrm{KU}$ & & $* *$ & $* *$ & $* *$ & $* *$ & $* *$ & $* *$ \\
\hline BU & & öd & $* *$ & öd & $* *$ & $* *$ & öd \\
\hline KU x BU & & öd & öd & * & $* *$ & $* *$ & $* *$ \\
\hline
\end{tabular}

Kuraklık uygulamaları: $\mathrm{K}_{1}$ : Normal sulama (kontrol), $\mathrm{K}_{2}: 1 \frac{1}{2}$ azaltılmıș, $\mathrm{K}_{3}: 3 / 4$ azaltılmış; Bakteri uygulamaları: $\mathrm{B}_{0}$ : Bakterisiz ortam(Kontrol), $\mathrm{B}_{1}$; Azospirillum lipoferum, $\mathrm{B}_{2}$ : Bacillus megaterium, $\mathrm{B}_{3}$ : Chlorella saccharophila, BU: Bakteri uygulamalar1, KU: Kuraklık uygulamaları, öd: önemli değil.

$* \mathrm{P}<0.05$ düzeyinde, $* * \mathrm{P}<0.01$ düzeyinde önemli olup, ortalamalar arasındaki fark Duncan çoklu karşılaştırma metoduyla $\mathrm{P}<0.05$ seviyesinde değerlendirilmiştir. 


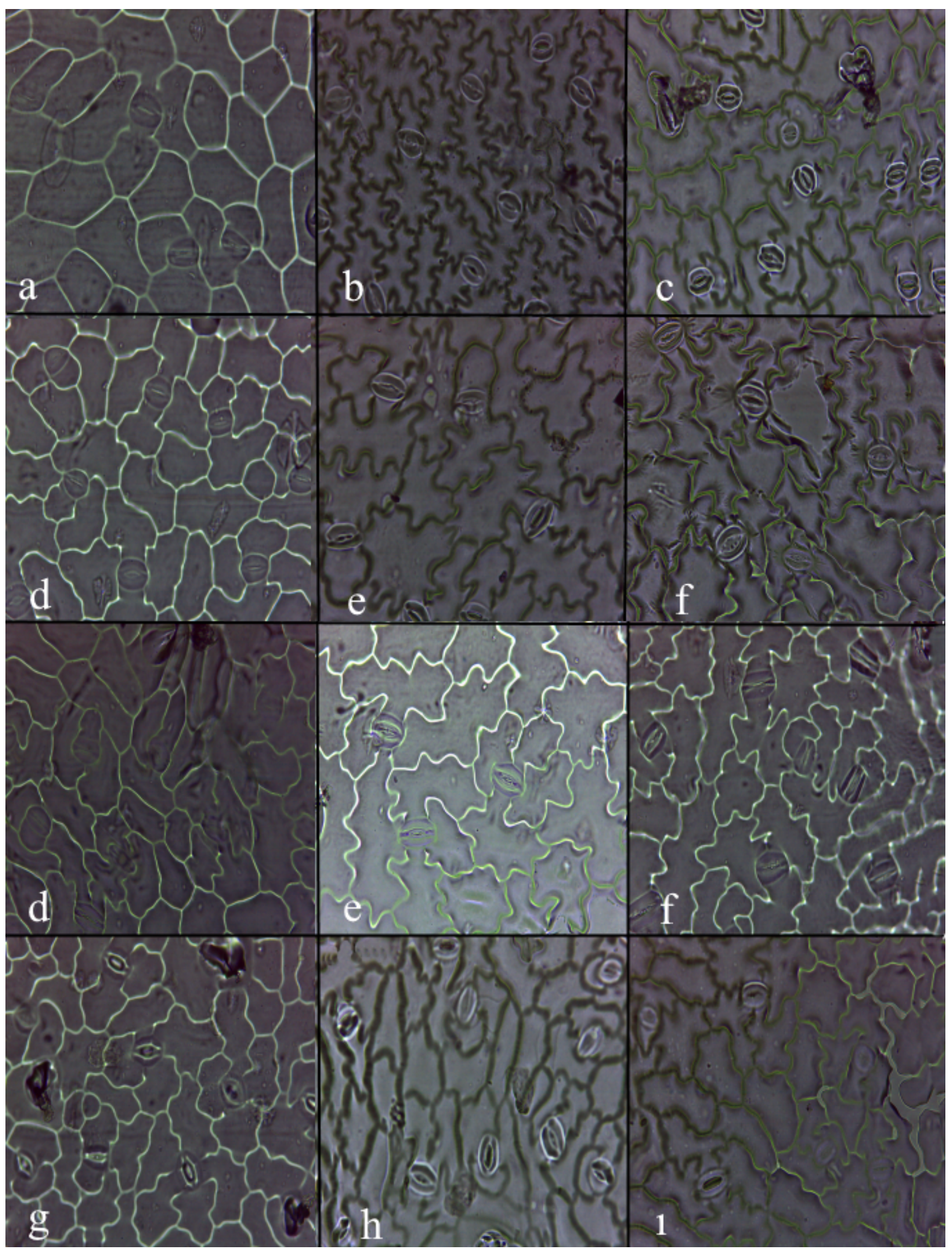

Şekil 1. C. officilis'e ait stoma ve epidermal hücreler (a: $\mathrm{B}_{0} \mathrm{~K}_{1}$, b: $\mathrm{B}_{0} \mathrm{~K}_{2}$, c: $\mathrm{B}_{0} \mathrm{~K}_{3}$, d: $\mathrm{B}_{1} \mathrm{~K}_{1}$, e: $\mathrm{B}_{1} \mathrm{~K}_{2}$, f: $\left.\mathrm{B}_{1} \mathrm{~K}_{3}, \mathrm{~g}: \mathrm{B}_{3} \mathrm{~K}_{1}, \mathrm{~h}: \mathrm{B}_{3} \mathrm{~K}_{2}, 1: \mathrm{B}_{3} \mathrm{~K}_{3}\right)$.

Son dönemlerde yapılan araştırmalarda kuraklık sorununun görüldüğü bölgelerde giderek yayılan BGUB uygulamaları ile stresin olumsuz etkisine karşı antioksidan enzim aktivitesindeki artış ile toleransın sağlanabileceği kaydedilmektedir (Sarma ve Saikia, 2014). Çalışmada elde edilen veriler ile kuraklık stresine karşı kullanılan bakterilerin bitki gelişim parametrelerinde etkili olduğu görülmüştür. 


\section{Sonuç}

Küresel ısınma ve bu 1sınmaya bağlı olarak meydana gelen kuraklık stresi dünyada tarımı olumsuz yönde etkilemekte ve bitkisel üretimde ciddi sorunlara sebep olmaktadır. Kuraklıkla oluşan bitkisel üretimdeki zararların önlenmesi açısından tedbirlerin alınması ve bitki gelişimini teşvik edici alternatif yöntemlerin geliştirilmesi büyük önem taşımaktadır. Günümüzde biyolojik gübrelerin tek veya kombinasyonlarının uygulandığı çalışmaların ön plana çıktığı görülmektedir. Bitki geliştirici mikroorganizmaların çoğunlukla azot ve fosfor alımında etkili olduğu belirtilse de diğer elementlerin de alınımını artırdığ morfolojik, ekolojik, fiziksel ve biyokimyasal değişimlerin ortaya konması ve strese dayanımı artırmak amacıyla bitki gelişimi teşvik edici uygulamaların meydana getirdiği değişimlerin belirlenmesi yetiştiricilik açısından ön açıcı olacaktır. Yapılan çalışmada farklı kuraklık uygulamalarına tabi tutulan C. officinalis bitkisinde bitki gelişimini teşvik edici bakterilerden $\mathrm{N}$ bakterisi olan Azospirillum lipoferum, P çözücü olarak bilinen Bacillus megaterium ve tatlı su algi olan Chlorella saccharophila'nın gelişim üzerine etkisi araştırılmış ve etkili sonuçlar elde edilmiştir. Bakteri uygulamalarında Bacillus megaterium bakterisinin gövde uzunluğu, kök yaş ağırlığı, gövde yaş ağırlığı, yaprak alanı, stoma boyu ve eninde en yüksek değerlere ulaştığı görülmüş ve kurak koşullarda $C$. officinalis' in gelişiminde etkili olduğu sonucuna varılmıştır.

Çalı̧̧manın sonucunda farklı kuraklık uygulamalarına tabi tutulan C. officinalis bitkisinin stres fizyolojisine bakıldığında oldukça dayanıklı olduğu görülmüştür. Kurak şartların hâkim olduğu bölgelerde alternatif bir tür olarak yetiştirilebileceği sonucuna varılmıştır. Farmakoloji, süs bitkileri, gıda ve kozmetik endüstrisinde değerlendirilme potansiyeli yüksek olan türün ülkenin her bölgesinde yetiştirilebileceği ve ekonomik olarak üretilme potansiyeli olduğu ön görülmektedir.

\section{Kaynakça}

Acıbuca, \& Budak D. B. (2018). Dünya'da ve Türkiye'de tıbbi ve aromatik bitkilerin yeri ve önemi. Çukurova Tarım ve Glda Bilimleri Dergisi, 33, 37-44.

Akçay, E., \& Eşitken, A. (2016). MM106 anacına ve üzerine aş11 golden delicious elma çeşidine tuz stresinin etkileri. Selçuk Tarım Bilimleri Dergisi, 3(2), 228-232.

Aşık, F. F., \& Arıoğlu, H. (2018). Ana ürün yerfıstığı tarımında bakteri (Rhizobium sp.) ve azotlu gübre uygulamalarının bazı tarımsal ve kalite özellikleri üzerine etkisi. Ç. Ü Fen ve Mühendislik Bilimleri Dergisi, 36-2.

Bahereh, K. A. (2020). Çinko $\left(\mathrm{Zn}^{+2}\right)$ toksisitesi koşullarında aynısefa (Calendula officinalis) bitkisinin morfolojik ve fizyolojik değişimlerinin ve fitoremediasyon potansiyelinin belirlenmesi. (Yüksek lisans tezi), Çukurova Üniversitesi, Fen Bilimleri Enstitüsü, Adana.

Bat, M., Tunçtürk, R., \& Tunçtürk, M. (2020). Ekinezya (Echinacea purpurea L.) bitkisinde kuraklık stresi ve deniz yosunu uygulamalarının bazı fizyolojik parametreler üzerine etkisi. Kahramanmaraş Sütçü İmam Üniversitesi Tarım ve Doğa Dergisi 23(1), 99-107.

Bolat, İ., \& Kara, Ö. (2017). Bitki besin elementleri: Kaynakları, işlevleri, eksik ve fazlalıkları. Bartın Orman Fakültesi Dergisi 19(1), 218-228.

Çağlar, S., Sütyemez, M., \& Bayazıt, S. (2004) Seçilmiş bazı ceviz (Juglan sregia) tiplerinin stoma yoğunlukları. Akdeniz Üniversitesi Ziraat Fakültesi Dergisi 17(2), 169-174.

Çınar, N., Aydinşakir, K., Dinç, N., Büyüktaş, D., \& Işık, M. (2016). Yerfıstığında (Arachis hypogaea L.) su stresinin stoma özellikleri üzerine etkisi. Mediterranean Agricultural Sciences 29(2).

Dere, S. (2021). Kuraklık Stresi Koşullarında Bakteri Uygulamasının Domates Bitkileri Üzerine Etkileri. Türk Doğa ve Fen Dergisi 10(1), 52-62. DOI: 10.46810/tdfd.805789

Doğan, A., Uyak, C., Akçay, A., Keskin, N., Gazioglu Şensoy, R. İ., Çelik, F., Kunter, B., Çavuşoğlu, Ş. \& Özrenk, K. (2020). Hizan (Bitlis) Koşullarında Yetiştirilen Üzüm Çeşitlerinin Klorofil Miktarları ve Stoma Yoğunluklarının Belirlenmesi. Yüzüncü Yıl Üniversitesi Tarım Bilimleri Dergisi, 30 (4) , 652-665. DOI: 10.29133/yyutbd.698508

Düzgüneş 0., Kesici, T., Koyuncu, O. \& Gürbüz, F. (1987). Araştırma ve deneme metotları. Ankara Üniversitesi Ziraat Fakültesi Yayınları, No:1021.295-381.

Ebcioğlu, N. (2013). "100 Şifalı Bitki 100 Şifalı İçecek,” Omega Yayınları. 
Ergün, O., Daşgan, Y. H., \& Işık, O. (2010). Su kültüründe yetiştirilen kıvırcık marul bitkisinde mikroalg (Chlorella vulgaris) uygulamasının etkileri. 9. Ulusal Sebze Tarımı Sempozyumu, Bildiriler: 12-14 Eylül 2012, Konya, s. 330-334

Eriş, A., \& Soylu, A. (1990). Stomatal density in various Turkish grape cultivars. Vitis, Special Issue, 382-389.

Göktaş, Ö., \& Gıdık, B. (2019). Tıbbi ve aromatik bitkilerin kullanım alanları. Bayburt Üniversitesi Fen Bilimleri Dergisi, 2(1), 145-151.

HtayHtay, O., Takuya, A., \& Fumitake, K. (2005). Effects of drought and flooding stresses on growth and photosynthetic activity of mungbean (Vigna radiata L.) wilczek, cultivars. Journal of the Faculty of Agriculture Kyushu University, 50(2), 533-542.

Jacoud, C., Faure, D., Wadoux, P., \& Bally, R. (1998). Development of a strain-specific probe to follow inoculated Azospirillum lipoferum CRT1 under field conditions and enhancement of maize root development by inoculation. FEMS Microbiol. Ecol., 27, 43-51.

Kalas, M. (2019). Eskişehir çevresinde yetişen bazı Calendula l. türleri üzerinde farmasötik botanik ve fitokimyasal araştırmalar (Yüksek Lisans tezi), Eskiş̧ehir Anadolu Üniversitesi, Sağlik Bilimleri Enstitüsü, Eskişehir.

Kara, Z., Doğan, O., Sabır, A., Özer, A., \& Koç, F. (2018). İtalya (Vitis Vinifera L.) Sofralık üzüm çeşidinde kısıtlı sulamanın yaprak ve stoma özelliklerine etkileri. Bahçe, 47(Özel Sayı 1), 677682.

Karipçin, M. Z. (2009). Yerli ve yabani karpuz genotiplerinde kuraklığa toleransin belirlenmesi (Doktora Tezi). Çukurova Üniversitesi Fen Bilimleri Enstitüsü, Adana.

Kurt, H., \& Doğan, A. (2020). Farklı Ekolojilerde Yetişen Fındık (Corylus avellana L.) Çeşit ve Genotiplerinin Stoma Yoğunluk ve Dağılımlarının Belirlenmesi. Yüzüncü Yıl Üniversitesi Tarım Bilimleri Dergisi, 30(3), 544-552.

Kusvuran, S., Ellıaltığlu, S., Abak, K., \& Yasar, F. (2007). Responses of some melon (Cucumis sp.) genotypes to salt stress. Journal of Agricultural Sciences. Ankara University Faculty of Agriculture, 13(4), 395- 404.

Kuşvuran, Ş., \& Abak, K. (2012). Kavun genotiplerinin kuraklık stresine tepkileri. Ç.Ü Fen ve Mühendislik Bilimleri Dergisi, 28(5), 79-87.

Kuşvuran, Ş., Daşgan, H. Y., \& Abak, K. (2008). Farklı bamya genotiplerinin kuraklık stresine tepkileri. VII. Sebze Tarımı Sempozyumu, 26-29 Ağustos, Yalova.

Kutsal, İ. K. (2017). Bitki büyümesini arttırıcı bazı rhizobakteri türlerinin sulu ve susuz koşullarda yetiştirilen kavunlarda bitki gelişimi ve meyve kalitesi üzerine etkileri (Yüksek lisans tezi), İnönü Üniversitesi Fen Bilimleri Enstitüsü, Malatya.

Liu, C., Liu, Y., Guo, K., Fan, D., Li, G., Zheng, Y., Yu, L., \& Yang, R. (2011). Effect of drought on pigments, osmotic adjustment and antioxidant enzymes in six woody plant species in karst habitats of southwestern china, Environmental and Experimental Botany, 71(2), 174-183.

Marasalı, B., \& Aktekin, A. (2003). Sulanan ve sulanmayan bă̆ koşullarında yetiştirilen üzüm çeşitlerinde stoma sayısının karşılaştırılması. Tarım Bilimleri Dergisi, 9(3), 370-372

Meidner, H., \& Mansfield, T. A. (1968). Physiology of stomata. Physiology of stomata. 179 pp. ref.Bibl. 177.

Meng, L., Li, L., Chen, W., Xu, Z., \& Liu, L. (1999). Effect of water stress on stomatal density, length, width and net photosynthetic rate in rice leaves. Journal of Shenyang Agricultural University, 30(5), 477-480.

Mert, C., Barut, E., \& Uysal, T. (2009). Farklı anaçlar üzerine aşılı elma çeşitlerinin stoma morfolojilerinin araştırılması. Tarım Bilimleri Araştırma Dergisi, 2(2), 61-64.

Obanda, M., \& Owuor, P. O. (1997). Flavanol composition and caffeine content of green leaf as quality potential indicators of Kenyan black teas. Journal of the Science of Food and Agriculture, 74, 209-215.

Özenç, D. B., \&, Şen, Ö. (2017). Farklı gelişim dönemlerinde uygulanan deniz yosunu gübresinin domates bitkisinin gelişim ve bazı kalite özelliklerine etkisi. Akademik Ziraat Dergisi, 6, 235242.

Öztekin, G., Tüzel, Y., Tüzel, Y., Ece, M., \& Ece, M. (2015). Fosfat çözücü bakteri aşılamalarının sera domates yetiştiriciliğinde bitki gelişimi, verim ve meyve kalitesi üzerine etkileri. Yüzüncü Yll Üniversitesi Tartm Bilimleri Dergisi, 25(2), 148-155. DOI: 10.29133/yyutbd.236367. 
Özyurt, İ. K. (2011). Kuraklı̆̆a dayanıklı mahlep (Prunus mahaleb L.) klon anacı seçimi (Doktora Tezi). Gaziosmanpaşa Üniversitesi Fen Bilimleri Enstitüsü, Tokat.

Samancıŏlu, A., Yıldırım, E., \& Şahin, Ü. (2016). Bitki gelişimini teşvik eden rizo bakteri uygulamalarının farklı sulama seviyelerinde yetiştirilen lahanada fide gelişimi, bazı fizyolojik ve biyokimyasal özellikler üzerine etkisi. Tarım ve Doğa Dergisi 19(3), 332.

Sarma, R. K., \& Saikia, R. (2014). Alleviation of drought stress in mung bean by strain Pseudomonas aeruginosa GGRJ21. Plant Soil 377, 111-126.

Sarker, B. C., \& Hara, M. (2011). Effects of elevated CO2 and water stress on the adaptation of stomata and gas exchange in leaves of eggplants (Solanum melongena L.). Bangladesh Journal of Botany 40(1), 1-8.

Şelem, E., Nohutçu, L., Tunçtürk, R., \& Tunçtürk, M. (2020). Bazı Allium Türlerinin Morfolojik Ölçümleri, Stoma ve Polen Özellikleri ile Polen Canlılığının Belirlenmesi. Yüzüncü Yll Üniversitesi Tarm Bilimleri Dergisi 30 (Ek sayı (Additional issue)), 882-889.

Sharm, S., \& Vig. P. A. (2013). Evaluation of in vitro antioxidant properties of methanol and aqueous extracts of Parkinsonia aculeata L. leaves, The Scientific World Journal, 1-7.

Tanker, N., Koyuncu, M., \& Coskun, M. (2007). Farmasötik Botanik. Ankara Üniversitesi Eczacıllk Fakültesi Yayınları no:93.

Telek, Ü., Akıncı, İ. E., \& Küsek, M. (2019). Rhizobakteri İzolatlarının Kırmızı Biberin (Capsicum annuum L.) Verim ve Bitkisel Özellikleri Üzerine Etkileri. Kahramanmaraşs Sütçü İmam Üniversitesi Tarım ve Doğa Dergisi 22(1), 62-70.

Tuteja, N., Gill, S. S., \& Tuteja, R. (2011). Plant responses to abiotic stresses: shedding light on salt, drought, cold and heavy metal stress. Omics and Plant Abiotic Stress Tolerance, 39-64.

Ünlükara, A., Kurunç, A., Kesmez, G. D., Yurtseven, E., \& Suarez, D. L. (2010). Effects of salinity on eggplant (Solanum melongena L.) growth and evapotranspiration. Irrigation and Drainage: The Journal of the International Commission on Irrigation and Drainage 59(2), 203-214.

Yolcu, H., Güneş, A., Güllap, M. K., \& Çakmakçı, R. (2012). Effects of plant growth-promoting rhizobacteria on some morphologic characteristics, yield and quality contents of Hungarian vetch. Turkish Journal of Field Crops 17(2). 208-214.

Yuwono, T., Handayani, D., \& Soedarsono, J. (2005). The role of osmotolerant rhizobacteria in rice growth different drought conditions. Australian Journal of Agricultural Research 56, 715-721. 